\title{
Effect of Soil Contamination on Biological Activities of Plant Species Growing in Peripheral Industrial Areas in Southeastern Tunisia
}

\author{
Ines Terwayet Bayouli ${ }^{1 *}$, Houssem Terwayet Bayouli², Ali Ferchichi ${ }^{2}$, Emna Ammar \\ ${ }^{1}$ Arid Regions Institute, Tunisia, Medenine, Tunisia \\ ${ }^{2}$ National Agronomic Institute of Tunis, Tunis, Tunisia \\ ${ }^{3}$ RU Costal and Urban Environments, National Engineering School of Sfax, University of Sfax, Sfax, Tunisia
}

Received: 11 October 2018

Accepted: 12 January 2019

\begin{abstract}
In recent decades industrial encroachment has affected many ecosystems including air, water and vegetation. Many plant species have revealed a strong capacity to survive in neighbourhoods of contaminated soil. Despite this, previous studies have emphasized the response of vegetation to heavy metals contamination, but none have examined those related to a cement plant's industrial effect. This study was conducted in Gabes cement plant peripheries in southeastern Tunisia, where Lygeum spartum, Gymnocarpos decander, Atractylis serratuloides and Stipa retorta were found to grow abundantly. The aim of this work is to assess the physiological response of these species that was carried out along four sites: S1, $(1 \mathrm{~km}), \mathrm{S} 2(3 \mathrm{~km}), \mathrm{S} 3(6 \mathrm{~km})$ and the control site SC $(12 \mathrm{~km})$ to evaluate their tolerance to heavy metals and to select the most appropriate species for a phytoremediation attempt. Significant variation $(p<0.05)$ was evidenced between sites in $\mathrm{Mg}^{2+}$ content, CAT, POD, GST, APX activities, proline and water content. Understanding the effect of heavy metals contamination on the physiological response was carried out through a correlations test. A strong positive correlation was marked between enzymatic activities and heavy metals as well as minerals. An increase of heavy metals content in plants was correlated by calcium content, which was followed by rising POD, APX and GST activities. Lygeum spartum enzymatic response was unaffected between sites with a slight decrease in the control site except for the APX activity reflecting a better adaptation and tolerance to contaminated conditions where the accumulation of heavy metals were revealed to be higher than in other plants.
\end{abstract}

Keywords: heavy metals, soil contamination, minerals, water content, antioxydative enzymatic response

*e-mail: Bayouli_ines@yahoo.fr 


\section{Introduction}

Even though the atmospheric emissions rate limits imposed on industrial facilities have become stricter in recent years, inadequate measures are still prevalent in the case of emergent countries [1,2]. Particulate matter and pollutants can be transported by the wind and dispersed by turbulent movement of air prior to reaching receptors. Among industries generating particulate matter, cement factories are listed at the top with huge dust emissions that are the main environmental concern in relation to cement manufacture [3]. These industrial units are important emission sources of both organic and inorganic chemicals, and produce metals and metalloid inputs such as $\mathrm{As}, \mathrm{Cd}, \mathrm{Ca}, \mathrm{Co}, \mathrm{Cr}, \mathrm{Cu}, \mathrm{Ni}, \mathrm{Pb}$ and $\mathrm{Zn}$ [3-5]. Gabes cement plant was created in 1977 and it supplies more than $25 \%$ of Tunisian needs. Despite this, the environmental effects related to the cement construction and operation were relatively localized; huge significant areas were affected. Indeed, the raw material quarrying, the industrial process leading to the final cement product and its transportation to the customer all contribute to different aspects inducing significant deleterious impacts [6]. Plant species and vegetation cover are among the primarily receptors of the cement dust and are subjected to the contamination delivered from the soils located in the industrial peripheries. Tolerant species are better able to adapt contaminated soils through their physiological defense system issued in response to the metallic stress induced [7]. Several studies have investigated the response of vegetation to heavy metals contamination [8], but none have examined those related to cement plant industrial effect. The aim of this work is to assess the physiological response of four species growing abundantly near Gabes cement plant and to evaluate their tolerance to heavy metals for selecting the most appropriate species for a phytoremediation attempt.

\section{Material and Methods}

\section{Study Area}

The study area is located around Gabes cement plant (Tunisia) between $33^{\circ} 51^{\prime} 57.61^{\prime \prime} \mathrm{N}$ in latitude and 9०59'38.85" E in longitude along four sites of $100 \mathrm{~m}^{2}$ surface each $\mathrm{S} 1$ at respectively $(1 \mathrm{~km}), \mathrm{S} 2(3 \mathrm{~km}), \mathrm{S} 3$ $(6 \mathrm{~km})$ and SC $(12 \mathrm{~km})$ from the cement plant. This factory is located $10 \mathrm{~km}$ northwest of Gabes city center, Tunisia. This region covers an area of $7.166 \mathrm{~km}^{2}$ and represents $7.9 \%$ of the total area of southern Tunisia [9], located in the Mediterranean rives, in the extreme southeast of the country, the vegetation is mainly characterized by the presence of a coastal oasis. The climate is characterized by dry air and a scarce and irregular rainfall that varies from 88 to $230 \mathrm{~mm} /$ year, large daily and annual temperature fluctuations with an annual temperature mean about $18.4^{\circ} \mathrm{C}$ and a long hot summer [10]. Collected species were Lygeum spartum, which is a perennial plant of the Poaceae family native to the southern Mediterranean Basin growing in arid soils, and Gymnocarpos decander species belonging to the Caryophyllaceae family. It is considered a rehabilitative species and adapted to the Mediterranean climate, and Atractylis serratuloides belongs to the family Astericaceae. This shrub is found in arid regions of Tunisia associated or not with other species and Stipa retorta belong to Poaceae that grows in industrial areas.

\section{Minerals}

The content of $\mathrm{Ca}, \mathrm{Mg}, \mathrm{K}, \mathrm{P}$, and $\mathrm{Na}$ were analysed in the plant material following [11]. The leaves of each species were ground and powdered by incineration in a muffle furnace at $500^{\circ} \mathrm{C}$ for 7 hours until no smoke occurred. Ash was cooled at room temperature, retrieved and embedded in sulfuric acid and reheated at $500^{\circ} \mathrm{C}$ until constant weight. One gram of ash was dissolved in $5 \mathrm{ml} \mathrm{HCL}$ and diluted to $50 \mathrm{ml}$ with distilled water until getting a solution. Minerals were analysed using atomic absorption spectroscopy (Shimadzu AA 6800, Kyoto, Japan).

\section{Heavy Metals}

The contents of total metallic elements were evaluated in the roots according to the protocol of acidic digestion of powdered plant material [12] following French Normalization NF 11465 designed for the determination of heavy metals contents in the plant species. Soil and plant material were ground and air dried until reaching constant weight. $0.5 \mathrm{~g}$ of each plant material were digested in $1 \mu \mathrm{l} \mathrm{HF} 3 \mathrm{ml} \mathrm{HNO}_{3}$ and $3 \mathrm{ml} \mathrm{H}_{2} \mathrm{O}_{2}$ after diluting the samples to $25 \mathrm{ml}$. Concentrations of $\mathrm{As}, \mathrm{Hg}, \mathrm{Zn}$ and $\mathrm{Pb}$ were determined using inductive coupled plasma spectroscopy (ICP-MS) on an Agilent 7700.

\section{Biological Activities Determination}

\section{Water Content (W)}

The leaves of the collected species were each weighed for determining the fresh weight first and then oven dried at $60^{\circ} \mathrm{C}$ until reaching constant weight. The dry weight was taken. The leaves were soaked with ultrapure water. The turgid leaves were reweighed. The water content was determined using the following formula: $\mathrm{W}=(($ Fresh weight - Dry weight $) /($ Turgid weight - Dry weight)) x 100 .

\section{Enzymatic Activities}

Enzymatic activities were determined following [13]. The tissues of Lygeum spartum were ground in a mortar added to the nitrogen liquid. The crushed samples were collected in $12 \mathrm{ml}$ Eppendorf tubes, to which $3 \mathrm{ml}$ of 
a $50 \mathrm{mM}$ potassium phosphate buffer solution at $\mathrm{pH}=7(0.1 \%$ triton $\mathrm{X}-100 \quad(\mathrm{v} / \mathrm{v}), 1 \%$ PVPP polyvinylpolypyrrolidone (w / v)) was added. Sample conservation was conducted at $4^{\circ} \mathrm{C}$. The samples were centrifuged for $15 \mathrm{~min}$ at $12000 \mathrm{~g}$. The supernatant is recovered and served as the extract for enzyme assay. The experimental protocol involves $3 \mathrm{ml}$ of $0.1 \mathrm{M}$ phosphate buffer $\mathrm{pH}=7$ and $0.1 \mathrm{ml}$ of $20 \mathrm{mM}$ hydrogen peroxide. According to the method of [14], the catalase activity is measured at $240 \mathrm{~nm}$ every minute directly after adding the enzyme extract over a maximum duration of 3 minutes and expressed

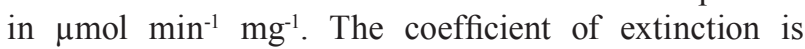
$39.4 \mathrm{mM}^{-1} \mathrm{~cm}^{-1}$. The peroxidase activity is determined according to the protocol described by [14] by mixing $0.5 \mathrm{ml}$ of the enzyme extract, $2 \mathrm{ml}$ of $0.1 \mathrm{M}$ phosphate buffer solution, $\mathrm{pH}=6.7$, and $1 \mathrm{ml}$ of $0.01 \mathrm{M}$ pyrogallol are added thereto, $1 \mathrm{ml}$ of $0.05 \mathrm{M} \mathrm{H}_{2} \mathrm{O}_{2}$. This mixture was incubated at $20^{\circ} \mathrm{C}$ for $5 \mathrm{~min}$ and added to $1 \mathrm{ml}$ of $\mathrm{H}_{2} \mathrm{SO}_{4}$. The absorbance is measured at $420 \mathrm{~nm}$ and expressed in units of 0.1 absorbance in $\mathrm{min}^{-1} \mathrm{mg}^{-1}$ protein. The coefficient of extinction is $26.6 \mathrm{mM}^{-1} \mathrm{~cm}^{-1}$. The ascorbate peroxidase activity is determined following the method of [15]. The reagents involved include $4 \mu \mathrm{l}$ of $\mathrm{H}_{2} \mathrm{O}_{2}(50 \mathrm{mM})$ and $40 \mu \mathrm{l}$ of enzyme extract in $956 \mu \mathrm{l}$ of phosphate buffer (50 mM, pH =7, $0.5 \mathrm{mM}$ ascorbate). Absorbance readings were noted at $290 \mathrm{~nm}$ along 3 minutes. The APX is measured every minute and expressed in $\mu \mathrm{M} \mathrm{min} \mathrm{mg}^{-1} \mathrm{mg}^{-1}$. The coefficient of extinction of $2.8 \mathrm{Mm}^{-1} \mathrm{~cm}^{-1}$. The glutathione-S- transferase is measured following the method described by [16]. The mixture contains $2.7 \mathrm{ml}$ of $0.1 \mathrm{M}$ phosphate buffer, $\mathrm{pH}=6.5,0.1 \mathrm{ml}$ of $50 \mathrm{mM}$ glutathione (in phosphate buffer $\mathrm{pH}=6.7), 0.1 \mathrm{ml}$ of $40 \mathrm{mM}$ Chloro-2,4 Dinitrobenzene CDNB (prepared in 95\% ethanol) and $0.5 \mathrm{ml}$ of the enzymatic extract. The absorbance readings were conducted at $340 \mathrm{~nm}$ for 5 minutes and expressed in $\mu$ mole de 1 chloro-2.4 Dinitrobenzène reacted to with the glutathion in one minute per $\mathrm{mg}$. The coefficient of extinction is $9.6 \mathrm{Mm}^{-1} \mathrm{~cm}^{-1}$. Enzymatic activities were measured according to the following formula:

$$
\begin{gathered}
\mathrm{W}=((\text { Fresh weight }- \text { Dry weight }) / \\
(\text { Turgid weight }- \text { Dry weight })) \times 100
\end{gathered}
$$

\section{Proline}

The method used is that of [17]. The leaves are crushed in a mortar in the nitrogen liquid until a powder is obtained. $200 \mathrm{ml}$ are added to $3 \mathrm{ml}$ of $3 \%$ sulfosalicylic acid. The mixture is centrifuged at $9000 \mathrm{rpm}$ for 15 minutes. After filtering, $1 \mathrm{ml}$ of glacial acetic acid and $1 \mathrm{ml}$ of ninhydrin reagent

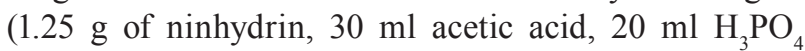
(6M)) are added to $1 \mathrm{ml}$ to the supernatant. After mixing, the sample is heated for 1 hour in a water bath at $90^{\circ} \mathrm{C}$ until pink color appears. After cooling the tubes, $2 \mathrm{ml}$ of toluene are added together with a pinch of $\mathrm{NaCl}$ to remove the residual water. The mixture is vortexed. After 24 hours of decantation, two phases appear, and the upper organic phase (toluene) contains proline. The proline content is determined spectrophotometrically. The optical density is measured at $515 \mathrm{~nm}$. The standards were prepared with proline concentrations between 0 and 40 nmoles.

\section{Statistical Analysis}

Variance analysis was conducted using ANOVA SPSS. 20 to assess the difference between mineral content averages of the species and heavy metals content. To analyse the relationship between enzymatic activities, water content and heavy metals, correlations using [18] Xlstat 2016 were carried out.

\section{Results and Discussion}

\section{Minerals Content}

Major elements such as nitrogen $(\mathrm{N})$, calcium $\left(\mathrm{Ca}^{2+}\right)$, phosphorus $(\mathrm{P})$, potassium $\left(\mathrm{K}^{+}\right)$and sodium $\left(\mathrm{Na}^{+}\right)$gain a major and discriminatory role in plant nutrition as well as in the transport and maintenance of the ionic balance along the roots, stems and leaves, but also in the soil-plant interaction [19]. Deficiency of these elements induces morphological, physiological and nutritional effects that are more explicit by inhibitory and slow-down effects on plant development, biochemical growth and disruption, including protein synthesis [20]. Results of minerals content are given in Fig. 1. The magnesium $\left(\mathrm{Mg}^{2+}\right)$ content in the leaves varies significantly between species $(p<0.05)$. The most abundant $\left(\mathrm{Mg}^{2+}\right)$ was marked in $L$. spartum species with an optimum concentration recorded in the control site (SC) (95.5 mg / 100g DW \pm 3.22$)$. Disregarding the intraspecific variation in $\mathrm{Mg}$ content, the species distributed at the control site exhibited in their leaf portions a maximum concentration of this nutrient, resulting in a better $\mathrm{Mg}^{2+}$ absorption reliability from soil. Otherwise, the calcium $\left(\mathrm{Ca}^{2+}\right)$ is mostly concentrated in species in the first site with a highest content of $\left[\mathrm{Ca}^{2+}\right]=144.14 \mathrm{mg} / 100 \mathrm{~g} \mathrm{DW} \pm 2.07$ marked in $L$. spartum. This concentration is attenuated in the (S2), (S3) to slightly increase at the control site with a content $87.71 \mathrm{mg} / 100 \mathrm{~g} \mathrm{DW} \pm 0,79$. The $\mathrm{Ca}^{2+}$ interspecific variation is mostly a non-significative $(p>0.05)$ exception of that measured in (S3). By comparing the potassium $\left(\mathrm{K}^{+}\right)$content in the four sites, an increase in potassium content in all species at the site (SC). G. decander was richer in $\mathrm{K}^{+}$with $\left(\left[\mathrm{K}^{+}\right]=111.5 \mathrm{mg} / 100 \mathrm{~g} \mathrm{DW} \pm 1.17\right)$ followed by L. spartum $\left(\left[\mathrm{K}^{+}\right]=105 \mathrm{mg} / 100 \mathrm{~g} \mathrm{DW} \pm 1.83\right)$. The intraspecific $\left(\mathrm{K}^{+}\right)$richness is almost similar in sites (S1) and (SC). The sodium content $\left(\mathrm{Na}^{+}\right)$was high in the first site than in the other sites, the species with the highest average in sodium foliar accumulation is $G$. decander 
a)

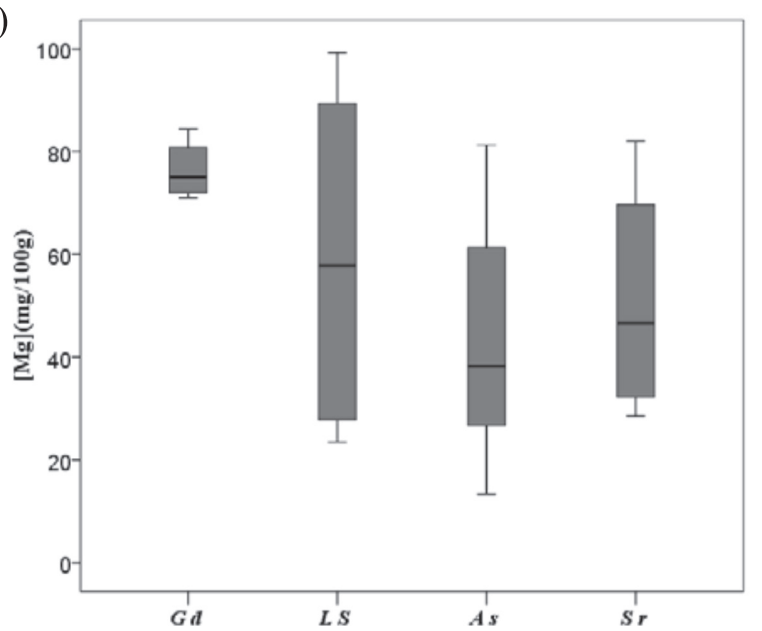

c)

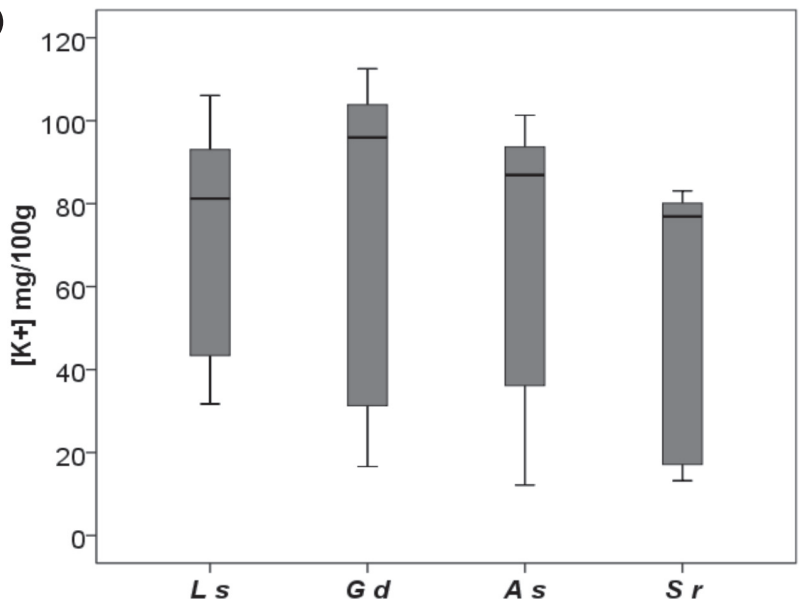

b)

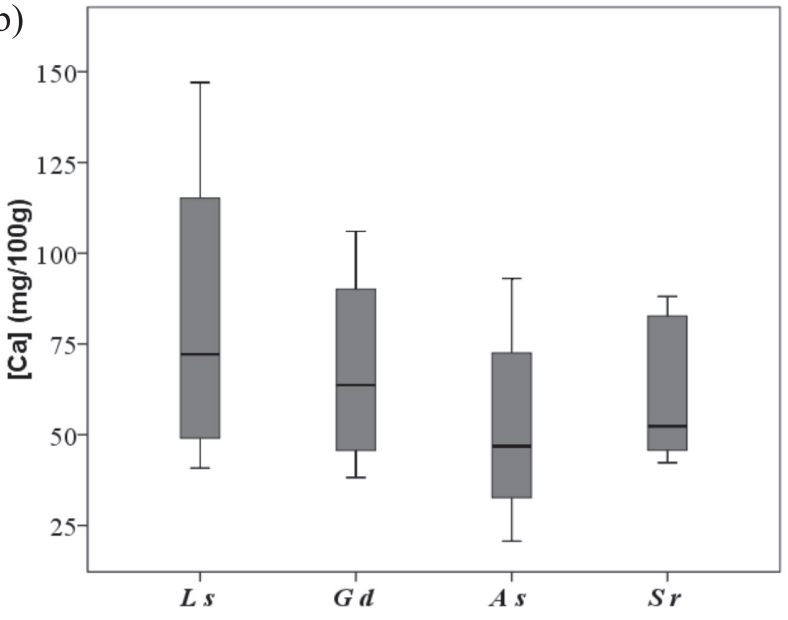

d)

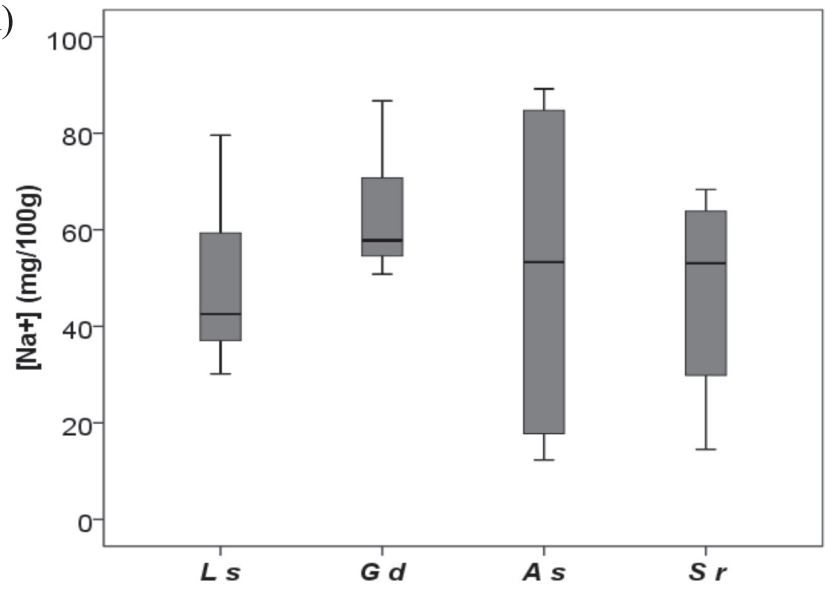

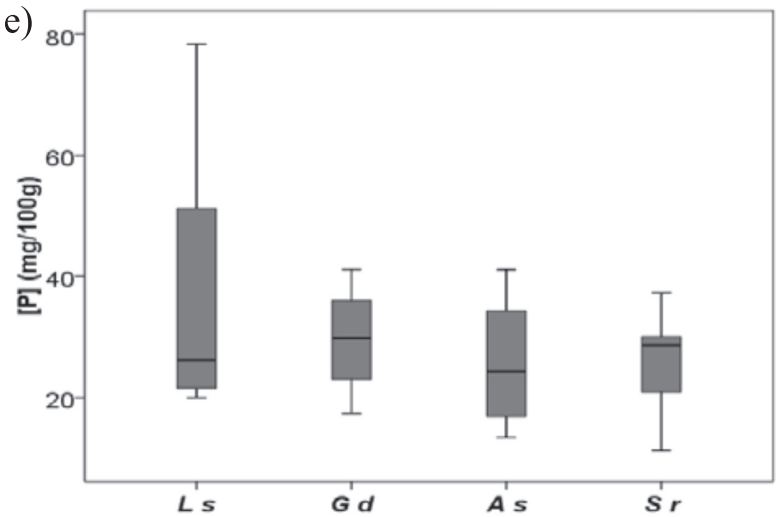

Fig 1. Boxplots of a): magnesium, b): Calcium, c): potassium, d): sodium, P): phosphorus contents expressed in mg/100g Dry weight (DW) in LS: Lygeum spartum, G d: Gymnocarpos decander, A S: Atractylis serratuloides, Sr: Stipa retorta with maximum and minimum contents registered in the studied sites.

with a maximum concentration of $84.86 \mathrm{mg} / 100 \mathrm{~g}$ DW. The enrichment at the first site is relative to the soil alkalinity $(\mathrm{pH}>7)$. In terms of quantities, phosphorus content (P) appears low in all four sites compared to other measured minerals. A significant interspecific variation $(p>0.05)$ is denounced by an optimum leaf $[\mathrm{P}]$ in the control site (SC) which gradually decreases to (S1). Although L. spartum retains the maximum of (P) ([with $\mathrm{P}]=76.68 \mathrm{mg} / 100 \mathrm{~g} \mathrm{DW} \pm 1.56)$, S. retorta is distinguished by a minor $(\mathrm{P})$ concentration in all sites. It should also be noted that the site (S1) is less rich in (P).

\section{Heavy Metals}

To better understand the metals' effect on the root zone and especially their effects on the plant physiological response, $\mathrm{As}, \mathrm{Hg}, \mathrm{Zn}$ and $\mathrm{Pb}$ contents were evaluated in the roots of L. spartum, G. decander, 
Table 1. Root heavy metals concentration evaluation $(\mathrm{n}=3 \pm \mathrm{SD})$ in Lygeum spartum, Gymnocarpos decander, Atractylis serratuloides and Stipa retorta.

\begin{tabular}{|c|c|c|c|c|c|}
\hline \multirow{2}{*}{ Species } & \multirow{2}{*}{$\begin{array}{c}\text { [Metal] } \\
\mu \mathrm{g} / \mathrm{g}\end{array}$} & \multicolumn{4}{|c|}{ Sites } \\
\hline & & S1 & S2 & S3 & $\mathrm{SC}$ \\
\hline \multirow{4}{*}{ L.S } & As & $8.84 \pm 1.32$ & $3.85 \pm 1.20$ & $1.90 \pm 0.24$ & $2.05 \pm 0.18$ \\
\hline & $\mathrm{Hg}$ & $4.15 \pm 0.02$ & $0.47 \pm 0.14$ & $0.17 \pm 0.03$ & $0.11 \pm 0.01$ \\
\hline & $\mathrm{Zn}$ & $17.36 \pm 0.03$ & $9.44 \pm 1.60$ & $8.05 \pm 0.04$ & $4.06 \pm 0.16$ \\
\hline & $\mathrm{Pb}$ & $99.03 \pm 0.98$ & $15.30 \pm 0.11$ & $3.35 \pm 0.08$ & $1.44 \pm 0.11$ \\
\hline \multirow{4}{*}{ G.d } & As & $3.56 \pm 0.44$ & $2.62 \pm 1.22$ & $0.45 \pm 0.19$ & $0.90 \pm 0.03$ \\
\hline & $\mathrm{Hg}$ & $1.10 \pm 0.08$ & $0.72 \pm 0.03$ & $0.32 \pm 0.03$ & $0.35 \pm 0.04$ \\
\hline & $\mathrm{Zn}$ & $10.60 \pm 0.70$ & $5.78 \pm 0.70$ & $4.62 \pm 0.50$ & $5.40 \pm 0.34$ \\
\hline & $\mathrm{Pb}$ & $56.12 \pm 0.33$ & $10.30 \pm 0.09$ & $3.63 \pm 0.11$ & $1.41 \pm 0.12$ \\
\hline \multirow{4}{*}{ A.S } & As & $0.44 \pm 0.03$ & $0.24 \pm 0.02$ & $0.32 \pm 0.05$ & $0.14 \pm 0.03$ \\
\hline & $\mathrm{Hg}$ & $1.63 \pm 0.25$ & $0.38 \pm 0.01$ & $0.22 \pm 0.01$ & $0.20 \pm 0.05$ \\
\hline & $\mathrm{Zn}$ & $16.55 \pm 0.45$ & $7.64 \pm 0.02$ & $7.16 \pm 0.04$ & $7.02 \pm 0.50$ \\
\hline & $\mathrm{Pb}$ & $76.78 \pm 2.72$ & $42.76 \pm 0.22$ & $34.44 \pm 2.42$ & $10.14 \pm 0.02$ \\
\hline \multirow{4}{*}{ S.r } & As & $6.36 \pm 0.06$ & $2.87 \pm 0.17$ & $2.94 \pm 0.03$ & $1.06 \pm 0.04$ \\
\hline & $\mathrm{Hg}$ & $9.05 \pm 0.25$ & $5.84 \pm 0.02$ & $5.48 \pm 0.00$ & $3.72 \pm 0.00$ \\
\hline & $\mathrm{Zn}$ & $4.63 \pm 0.03$ & $2.17 \pm 0.01$ & $0.71 \pm 1.69$ & $0.52 \pm 0.12$ \\
\hline & $\mathrm{Pb}$ & $58.30 \pm 1.19$ & $17.34 \pm 0.02$ & $22.13 \pm 1.41$ & $11.60 \pm 0.70$ \\
\hline
\end{tabular}

A. serratuloides and $S$. retorta (Table 1). The intraspecific variation exihibits an optimum root concentration recorded in L. spartum $(p<0.05)$. A gradual decline in the metal concentration between the first site $\mathrm{S} 1$ and the distant control site SC was noted in L. spartum, $G$. decander, S. retorta and A. serratuloides, where As, $\mathrm{Hg}, \mathrm{Zn}$ and $\mathrm{Pb}$ revealed with low concentrations in the control site SC. Although all metal concentration decreased in the control site, each has a different affinity to accumulate metals. For $L$. spartum, the highest root accumulation appeared in the first site with $\mathrm{Pb}$ metal $(99.03 \mu \mathrm{g} / \mathrm{g})$; however, the lowest value was in the control site with $\mathrm{Hg}(0.11 \mu \mathrm{g} / \mathrm{g})$. In $G$. decander metals accumulation ranges from $[\mathrm{Hg}]=0.35 \mu \mathrm{g} / \mathrm{g}$ to

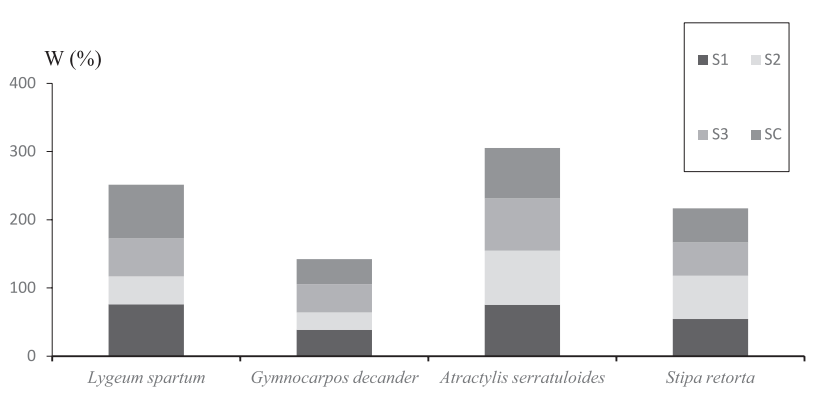

Fig 2. Variation of water content $(\mathrm{W})(\mathrm{n}=3)$ in percentage (\%) Lygeum spartum, Gymnocarpos decander, Atractylis serratuloides and Stipa retorta in the studied sites.
$[\mathrm{Pb}]=56.12 \mu \mathrm{g} / \mathrm{g}$. In $A$. serratuloides the lowest accumulation was for As $(0.44 \mu \mathrm{g} / \mathrm{g})$ to $76.78 \mu \mathrm{g} / \mathrm{g}$ for $\mathrm{Pb}$. In $S$. retorta, $[\mathrm{Zn}]=0.52 \mu \mathrm{g} / \mathrm{g}$ reveals the lowest to $[\mathrm{Pb}]=58.3 \mu \mathrm{g} / \mathrm{g}$. This latter has evidenced a strong variation of metals accumulation between (S1) and (SC).

\section{Water Content}

Water content is one of the most important parameters in understanding plant physiology as well as its properties. Indeed, it is a relevant indicator of good physiological functioning through the plant matrix. The water status of plant species is often controlled by an optimal value, beyond which all biological activities can be disturbed or in some cases inhibited [21]. The variation in water content (Fig. 2) in L. spartum, G. decander, A. serratuloides and $S$. retorta showed an interspecific variation in water content. The lowest water content was marked in A. serratuloides. This is reportable to the foliage type of $A$. serratuloides, characterized by a rigid to thorny structure unlike $G$. decander, which was revealed to a certain extent with succulent leaves. The lower water content of this plant $(25 \%)$ revealed at the second site elucidates the desiccation and reflects a water balance disturbance of the plant by a dysfunction in the root level, and the occurrence of water resources deficit in the soil matrix that other species could adapt to. 


\section{Antioxydative Response}

\section{Catalase (CAT)}

The CAT activity shown in Fig. 3a) exhibited a variation in catalase activity according to site and species. The highest activity is noted in $S$. retorta, with $0.81 \mu \mathrm{mol} \mathrm{min}{ }^{-1} \mathrm{mg}^{-1}$, although the lowest activity is marked in A. serratuloides. The result run by Tukey's test showed a significant difference for $G$. decander, $A$. serratuloides and $S$. retorta $(p<0.05)$, and a nonsignificant difference for L. spartum $(p=0.2>0.05)$. Highest concentrations in the first site could be related to a higher heavy metals contamination in site S1. Otherwise, the increased activity in $S$. retorta explained a higher antioxidative response toward heavy metals in the first site. A less adaptable species requires a high antioxidative response.

\section{Peroxidase Activity (POD)}

The peroxidases are enzymes located in the plant species - especially in the cell walls. POD activities usually increase with metallic stress and can be considered as a biological bioindicator. The peroxidase family is part of the complex defensive system and it is a biological determinant of plant pathologies [22]. A significant difference in POD activity shown in Fig. 3b) of each species between sites $(p<0.05)$ was registered. In the close site to the plant, the species with the highest POD activity was $S$. retorta (53.52 $\mathrm{Umin}^{-1} \mathrm{mg}^{-1}$ protein). However, it was marked by the lowest in the control site with an activity of $0.41 \mathrm{Umin}^{-1} \mathrm{mg}^{-1}$ protein. The descending order of POD was as follows: $S$. retorta $>G$. decander $>A$. serratuloides $>$ L. spartum.

\section{Glutathione-S-transferase (GST) Assay}

Glutathione -S-transferases are enzymes that catalyze the conjugation of GSH tripeptide glutathione to hydrophobic, electrophilic and cytotoxic substrates. The GSTs are often associated with the detoxification of xenobiotics limiting deleterious oxidative effects and other effects [23]. Variance analysis showed a significant difference in $L$. spartum, $G$. decander, A. serratuloides and $S$. retorta $(p<0.05)$. At the first site, the GST activities (Fig. 3d) were ranked in descending order

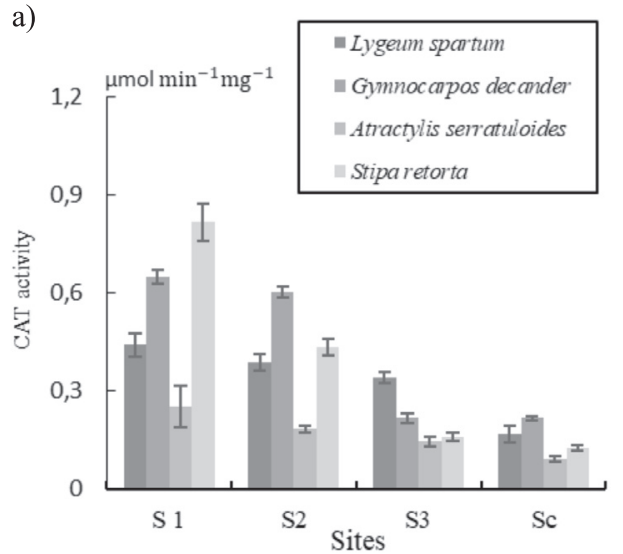

(c)

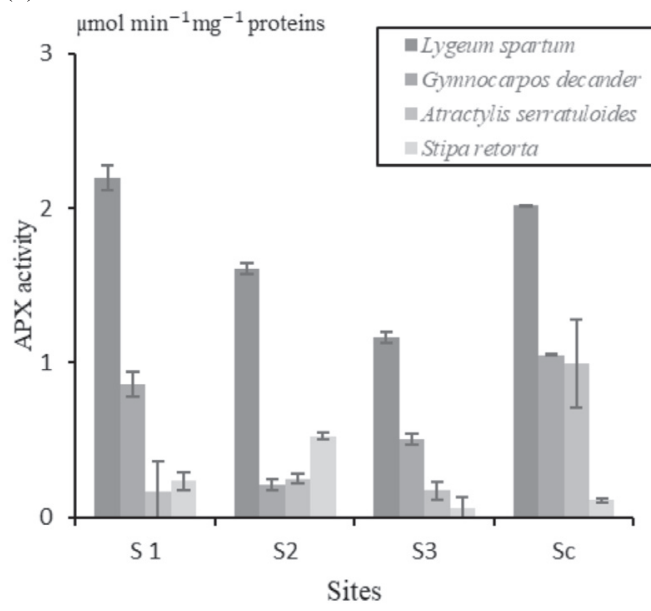

b)

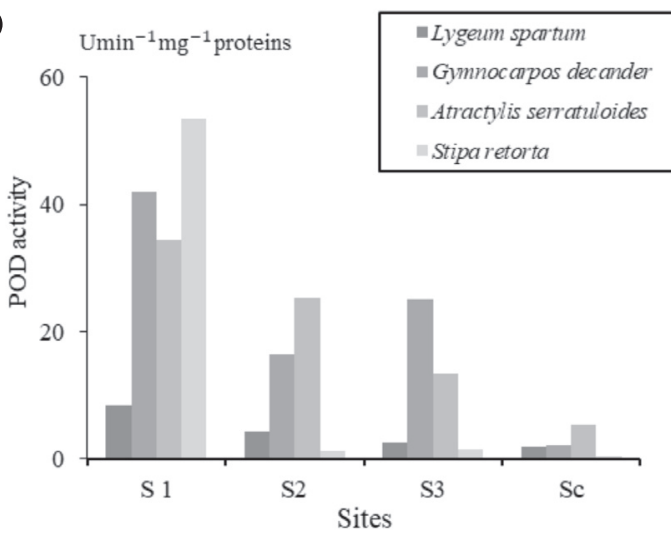

d)

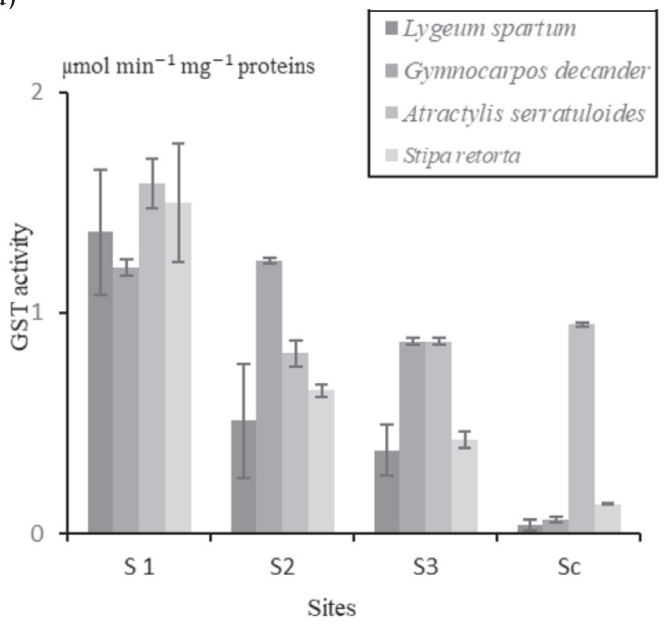

Fig 3. Enzymatic activity variation $(n=3)($ Means \pm SD) of a): catalase $(\mathrm{CAT}), \mathrm{b})$ : peroxidase (POD), c): ascorbate peroxidase $(\mathrm{APX})$ and d): Glutathione-S-Transferase (GST) in Lygeum spartum, Gymnocarpos decander, Atractylis serratuloides and Stipa retorta in the studies sites. 
as follows: $A$. serratuloides $>S$. retorta $>$ L. spartum $>G$. decander. The highest GST activity is marked in the first site in $A$. serratuloides with an optimum of $1.58 \mu \mathrm{mol} \mathrm{min} \mathrm{mg}^{-1}$ protein, while the lowest activity was recorded at the fourth site in L. spartum $\left(0.03 \mu \mathrm{mol} \mathrm{min} \mathrm{mg}^{-1}\right), G$. decander $\left(0.05 \mu \mathrm{mol} \mathrm{min} \mathrm{mg}^{-1}\right)$,

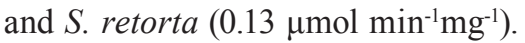

\section{Ascorbate Peroxidases (APX)}

The ascorbate peroxidase (APX) is one of the enzymes secreted when the reactive oxygen species (ROS) production increases in plant cells and whose essential role is to detoxify these ROS. The APX plays a catalytic role in the cycle of ascorbate glutathione by the conversion of $\mathrm{H}_{2} \mathrm{O}_{2}$ to $\mathrm{H}_{2} \mathrm{O}$ [24]. The APXs interfere directly in the protection of plants from different abiotic stresses. A very high variation between L. spartum, G. decander, A. serratuloides, and $S$. retorta was noticed with $p<0.05$. The highest APX (Fig. 3c) activity was exhibited in L. spartum of

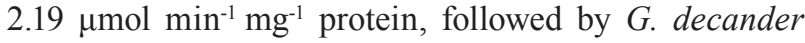
at a level of $1.60 \mu \mathrm{mol} \mathrm{min} \mathrm{mg}^{-1} \mathrm{mg}^{-1}$ protein at the first site. The lowest activity is recorded at the third site in $S$. retorta $\left(0.02 \mu \mathrm{mol} \mathrm{min}^{-1} \mathrm{mg}^{-1}\right.$ proteins).

\section{Proline Assay (pro)}

In the face of various environmental constraints, proline is one of the solutes accumulated during the plant tolerance mechanisms. This protein component plays a free radical scavenging role and regulates the cellular redox potential in addition to its stabilizing role of proteins and macromolecular complexes [25]. The different proline concentrations of the four species are given in Fig. 4. The proline assay varies between $L$. spartum, $G$. decander, A. serratuloides and $S$. retorta according to the Student Newman Keuls SNK test $(p<0.05)$. The highest concentration of proline is noted in $S$. retorta at the first site ( $\mathrm{S} 1$ ), with a proline content of $19.60 \mu \mathrm{mol} \mathrm{g}{ }^{-1} \mathrm{DW}$. The second site (S2), the third site (S3) and the control site (SC) are characterized by the lowest proline concentrations ranging from 1.90 to $7.15 \mu \mathrm{mol} \mathrm{g}{ }^{-1}$ DW.

\section{Discussion}

The mineral richness in the species varies according to the sites. There is a decrease in physiological assimilation depending on the soil chemical composition. This would be either related to the quantitative abundance of these minerals in soils, or also to the response of the species themselves to contamination as the first site is the closest to the source of contamination. However, the furthest control site (SC) was uncontaminated. The mineral analysis in the studied species showed richness in mineral elements in L. spartum, followed by $G$. decander compared to other

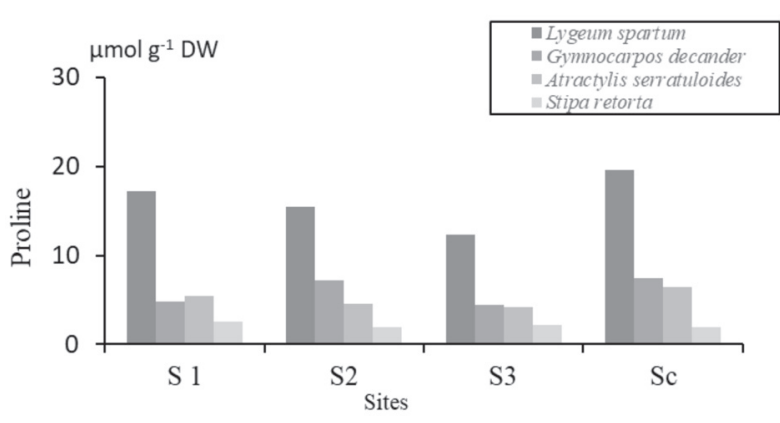

Fig 4. Variation of proline content $(\mathrm{n}=3)($ means $\pm \mathrm{SD})$ in Lygeum spartum, Gymnocarpos decander, Atractylis serratuloides and Stipa retorta in the studied sites.

species. For better minerals uptake in plant species, these plants have evolved highly-efficient systems for mineral uptake, storage and translocation [26, 27]. Minerals uptake by plants depends on the development of a root system where a large root mass, long root length and a large root hair cylinder volume (RHCV) enables greater soil exploration and are recognized as adaptations for increasing minerals uptake and fast growth [28, 29], which would rationalize the development of L. spartum roots and hence a better uptake. The high concentration of $\mathrm{Mg}$ could be explained by a more efficient absorption or $\mathrm{Mg}$ bioavailability depending on the type of soil where alkalinity improves the capacity of cationic change CEC while low $\mathrm{Mg}$ availability is associated with acidic soils [30]. Indeed, the adaptation of these species to the environment under stress such as contaminated media can give them an easy absorption of minerals. Since $\mathrm{Mg}$ plays a key role in enzymatic activation, it provides better protection against parasitic chlorophyllian attacks and also enters into the biosynthesis of carotenes and xanthophylls [31, 32]. This element could add to the sparte species better resistance to metallic stress affecting the morphology. The $\mathrm{Mg}$ is also involved in the transfer of phosphorus (P). This high $\mathrm{Mg}$ content can give protection against chlorosis and necrosis by providing ideal growth [33, 34]. Similarly, calcium is better assimilated by L. spartum than other species. One of the cell wall constituents is the calcium that provides several functions in the neutralization of organic acids as well as inducing enzymatic activities as precursors [29]. This calcium content procures to L. spartum species resistance against wilting and malformation of terminal bud plant that may appear in a state of calcium deficiency [35]. Various studies have elucidated the role of calcium in the mitigation of deleterious effects in many accumulator species such as Brassica juncea, Matricaria chamomilla, and Lens Culinaris L [36-38], which may highlight the contribution of $\mathrm{Ca}^{2+}$ to metal tolerance in L. spartum. The analysis of the potassium content $\left[\mathrm{K}^{+}\right]$reveals a better foliar accumulation in $G$. decander followed by $L$. spartum. This element participating in cell growth is essential for plant survival. Its abundance is always given to the plant's dry matter, 


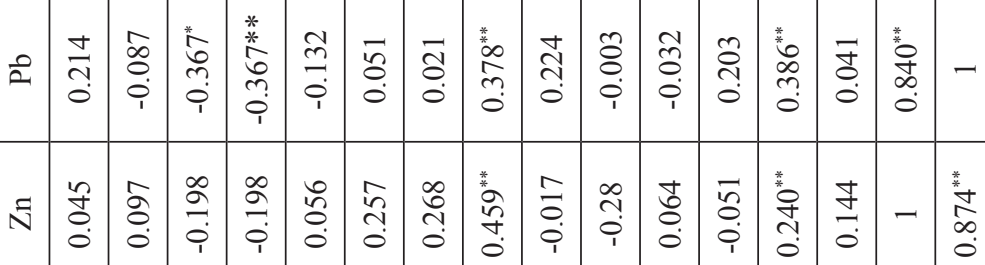

DD

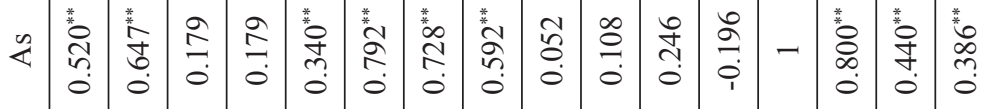

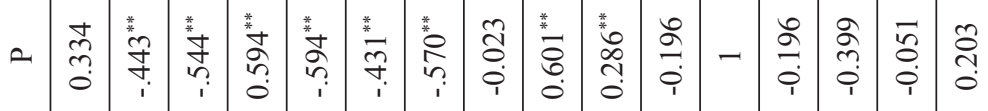

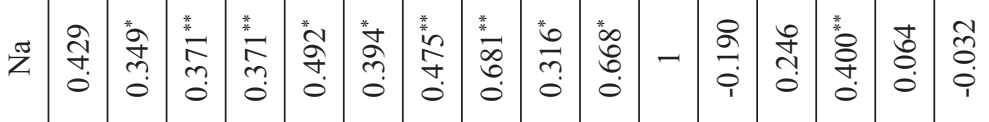

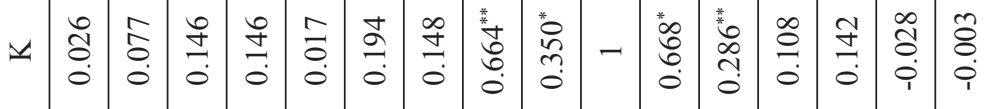

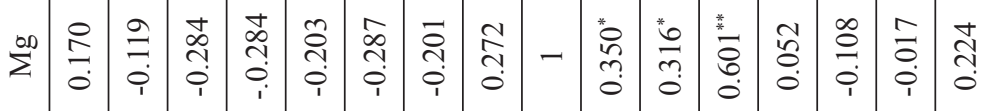

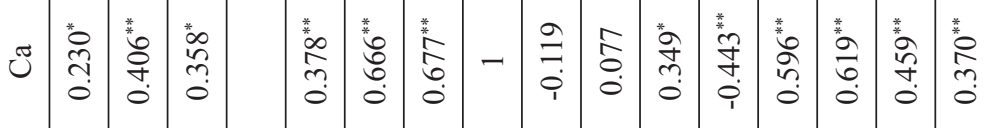

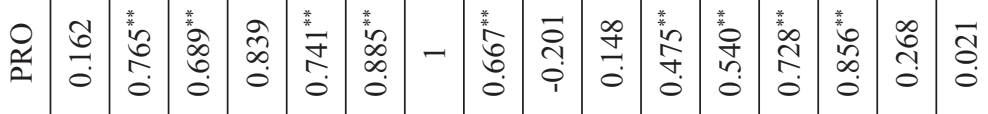

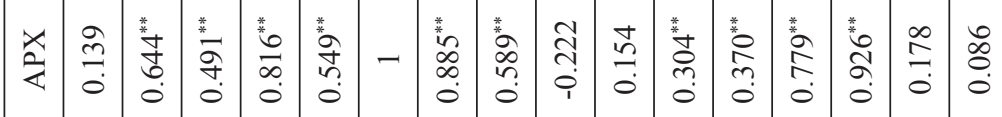

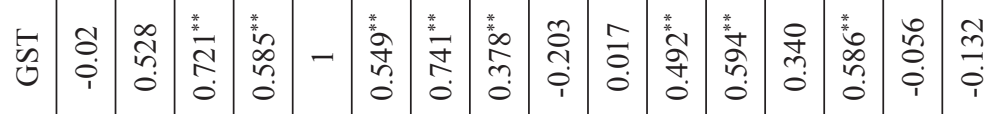

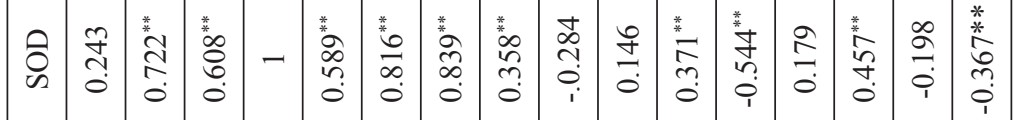

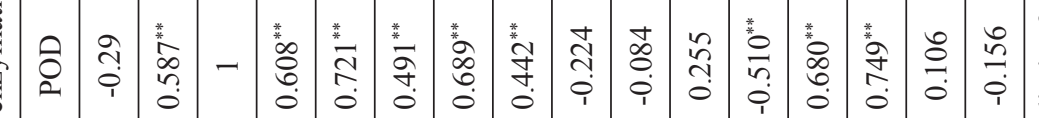

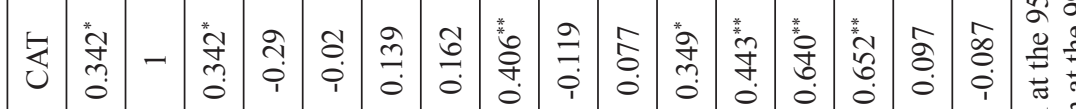

兽

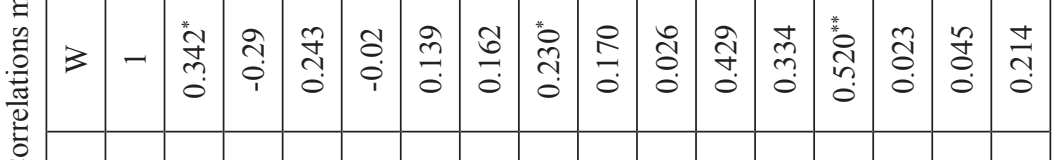

3 它领 
its role is essential in the activation of the enzymatic machinery and consequently in the photosynthesis. It ensures proper physiological functioning through the transfer of nutrients from roots to the aerial parts. In addition, potassium controls the stomata closure and opening depending on the surrounding conditions, in addition to its major role in water regulation [39, 40]. In a study conducted by [41], potassium was found to imprint biomass, growth, and antioxidant enzymatic machinery in a Cd-contaminated environment. Phosphorus (P) is strongly retained by $L$. spartum in comparison with other species. This mineral element acquires a structural importance due to its contribution in the plants skeleton as well as in the energies generation since it is one of the essential components of ATP molecules. Its integral role in the cell multiplication of meristems makes it essential for species development as well as for respiration and, among other things, photosynthesis [42, 43]. In a study developed by [44], phosphorus was found to inhibit heavy metals and by their immobilization in soil. The mineral analysis elucidates a better assimilation of $L$. spartum and to a lesser extent the $G$. decander of the set of analyzed minerals. This can be dismantled in the development of an L. spartum root system with a rigid underground mass with extended, long and condensed roots as well as dense absorbent hairs that allow for better reliable mineral absorption compared to other species tested. This reflects the proliferation also of foliar volume of this species [45]. A mineral richness could have a contribution in the enzymatic defence against the oxidative stress initiated by soil contamination throughout reinforcing the enzymatic machinery cascade and also in the morphology and physiological balance maintain against the disturbances that can generate inorganic and organic metal contamination [22].

All enzymatic activities are strongly linked to each other by highly significant positive correlations. Correlations are applied similarly to all the enzymatic activities with the mineral contents and the heavy metals contents (Table 2). Calcium content is strongly related to all enzyme activities (CAT, POD, GST, and APX) as well as the set of heavy metals (As, Hg, $\mathrm{Zn}$ and $\mathrm{Pb}$ ). This positive correlation can elucidate the role of calcium in the enzymatic synthesis in plants. The same applies to the sodium content, which relates to all enzyme activities but only with $\mathrm{Hg}$. Phosphorus (P) is negatively correlated with enzymatic activities and heavy metals. Any increase in P causes a decrease in the other parameters. A direct bond is determined between $\mathrm{Hg}$ and As with other minerals and with the enzymes tested. This corroborates with the study conducted by [46], which shows an increase in most antioxidant enzymatic activities following an increase in $\mathrm{Zn}$ content in lettuce. Higher concentrations of catalase and ascorbate peroxidase have been observed in $P$. vittata prone to arsenic treatment showing an enzyme active involvement in the arsenic detoxification mechanism as evidenced by [47]. According to [48], results of antioxidant enzymes showed that activities of the antioxidant enzymes, CAT, SOD, POD and APX increased in both leaves and roots under $\mathrm{Cd}$ and $\mathrm{Pb}$ stress. We found that the increment of antioxidant enzymes under metal stress confers to these plant species better adaptation and survival in contaminated areas while contributing to the protection of the photosynthetic apparatus [49, 50]. Plant species react to contaminants differently where they have diverse strategies to heavy metals tolerance [50]. This is dealing with our results where L. spartum, G. decander, A. serratuloides and $S$. retorta have shown a significant variance in metal accumulation. This may be linked to differences in ROS accumulation, lipid peroxidation and antioxidant enzyme expression, which may vary from sensitive metal species to accumulator species according to Rhui [51].

\section{Conclusions}

A contamination in the closest site to the cement plant was marked by a maximum of $\mathrm{As}, \mathrm{Pb}$, and $\mathrm{Hg}$ concentrations in plants growing near sites where L. spartum was revealed with the highest metal contents accumulation. No variation in minerals was recorded between sites except for magnesium. The $\mathrm{pH}$ variation affects the enzymatic activities as well as heavy metals contents. POD, APX, CAT and GST were positively correlated.

\section{Acknowledgements}

We thank Professor Houcine Khatelli, director of the Arid Regions Institute, Tunisia for all help - including the generous use of facilities for conducting our work. We thank the Commissariat Regional of Research and Development of Gabes for their generous field data.

\section{Conflict of Interest}

The authors declare no conflict of interest.

\section{References}

1. GABRIELA A., ABI L., EDUARDO D., WANNAZ ANA C., MATEO S., MARIA L., PIGNATA Biomonitoring of airborne particulate matter emitted from a cement plant and a comparison with dispersion modelling results. Atm Env. 154 (82), 163, 2014.

2. YANG Z., GE H., LU W., LONG Y. Assessment of heavy metals contamination in near surface dust. Pol.J. Environ. Stud. 1425 (24) 1426, 2015.

3. ISIKLI B., DEMIR T., AKAR T., BERBER A., URER S.M., KALYONCU C., CANBEK M. Cadmium exposure from the cement dust emissions. A field study in around residence, chemosphere. 1546 (63), 552, 2006. 
4. SCHUHMACHER M., JOSE L., GARRETTA D.J. Pollutants emitted by a cement plant: health risks for the population living in the neighborhood. Env Res. 198 (95), 206, 2004.

5. ALKASHMAN O., SHAWABKEH R.A. Metal distribution in soils around cement factory in southern Jordan. J. Env Pol. 387 (140), 394, 2006.

6. HAYDAR A. Industrialisation de gabes et ses conséquences. Etude géographie urbaine et économique. Édité par l'université de Tunis Faculté des lettres et sciences humaines de Tunis. Imprimerie officielle tunisienne. 1 (19), 194, 1986.

7. CLEMENS S. Toxic metal accumulation, responses to exposure and mechanisms of tolerance in plants. Biochimie. 1707 (11), 1719, 2006.

8. NADGORSKA-SOCHA A., KANDZIURA-CIUPA M., CIEPAL R., WALASEK K. Effect of $\mathrm{Zn}, \mathrm{Cd}, \mathrm{Pb}$ on physiological response of Silene Vulgaris Plants from selected populations. Pol. J. Envi. Stud, 599 (3) 604, 2011.

9. Commissariat Régional de Développement et d'Agriculture (CRDA). Le gouvernorat de Gabès en chiffres en 2005. Ministère de développement économique. Office de développement du su. Editions de CRDA. 1, 2005.

10. www.meteo.tn

11. AOAC., Official methods of analysis. Association of analytical Chemist. UUA Chemical, 2000.

12. ESEN C., BALCI A. Applications of microwave assisted digestion to trace heavy metals determination in sea sediment sample. Hacettepe J Bio and Chem. 123 (36), $128,2008$.

13. BENHAMDI A., BENTELLIS A., RACHED O., DU LAING G., MECHAKRA A. Effects of antimony and arsenic on antioxidant enzyme activities of two steppic plant species in an old antimony mining area. Biol. Trace Elem. Res. 96 (158), 104, 2014.

14. CHANCE B., MACHLY A.C. Methods of biochemical analysis In: Glick D (ed) Interscience Publishers Inc., New York. 1967.

15. NAKANO Y., ASADA K. Spinach chloroplasts scavenge hydrogen peroxide on illumination. Plant Cell Physiol. 1295 (21), 1307, 1980.

16. HABIG W.H., JAKOBY W.B. Assays for differentiation of glutathione S-transferases. Methods Enzymol. 398 (77), 405, 1981.

17. BATES L. Rapid determination of free proline for waterstress studies. Plant Soil. 205 (39), 207, 1973.

18. Addinsoft. 2016. XLSTAT 2016: Data Analysis and Statistical Solution for Microsoft Excel. Paris, France, 2016.

19. JACOBY R., PEUKERT M., SUCCURRO A., KOPRIVOVA A., KOPRIVA S. The role of soil microorganisms in plant mineral nutrition-current knowledge and future directions. Frontiers in Plant Science 19, 1617, 2017.

20. KALAJI M.H., RUTKOWSKA A. Reactions of photosynthetic apparatus of maize seedlings to salt stress. Zesz Probl Post NaukRol. 545 (496), 558, 2004.

21. DE PARCEVAUX S., BERTOLINI J.M., KATERJI N. Masse en eau des feuilles : détermination non destructive en milieu naturel. Agronomie. 547 (15), 556, 1995.

22. GUO Q., LI H., LUO D., QUAN H., BIANBA D., ZHANG W. Comparative drought tolerance of six native deciduous and broad-leaved woody plant species seedlings in the Qinghai-Tibet Plateau. Acta Physiol Plant. 1 (38), 14, 2016.

23. MARTINEZ V., NIEVES-CORDONES M., LOPEZDELACALLE M., RODENAS R., MESTRE T.C.,
GARCIA-SANCHEZ F., RUBIO F., NORTES P.A., MITTLER R., RIVERO R.M. Tolerance to stress combination in tomato plants: new insights in the protective role of melatonin. Molecules. 535 (23), 560, 2018.

24. SOFO A., SCOPA A., NUZZACI M., VITTI A. Ascorbate peroxidase and catalase activities and their genetic regulation in plants subjected to drought and salinity stresses. Intl J Mol Sci. 13561 (16), 13578, 2015.

25. REJEB K.B., ABDELLY C., SAVOURÉ A. How reactive oxygen species and proline face stress together. Plant Physiol. Biochem. 278 (80), 284, 2014.

26. CHEN Z.C., WEN TING PENG W.T., JIAN LI J., LIAO H. Functional dissection and transport mechanism of magnesium in plants. Seminars in Cell \& Developmental Biology. 142 (74), 152, 2018.

27. PINTO E., FERREIRA I. Cation transporters/channels in plants: Tools for nutrient biofortification. Journal of Plant Physiology. 64 (179) 82, 2015.

28. WADDELL H.A., SIMPSON R.J., RYAN M.H., LAMBERS H., GARDEN D.L., RICHARDSON A.E. Root morphology and its contribution to a large root system for phosphorus uptake by Rytidosperma species (wallaby grass). Plant and Soil, 412 (1-2), 7, 2016.

29. SINGH R., PARIHAR P., PRASAD S.M. Simultaneous exposure of sulphur and calcium hinder As toxicity: Up-regulation of growth, mineral nutrients uptake and antioxidants system. Ecotoxicology and Environmental Safety. 318 (161), 331, 2018.

30. TANG R.J., LUAN S. Regulation of calcium and magnesium homeostasis in plants: from transporters to signaling network. Curr Opin Plant Biol. 97 (39), 105, 2017.

31. GUO W., NAZIM H., LIANG Z., YANG D. Magnesium deficiency in plants: An urgent problem. The Crop Journal, 83 (4), 91, 2016.

32. HUANG Y., JIAO Y., NAWAZ M.A., CHEN C., LIU L., LU Z., KONG Q., CHENG F., BIE Z. Improving magnesium uptake, photosynthesis and antioxidant enzyme activities of watermelon by grafting onto pumpkin rootstock under low magnesium. Plant and Soil, 409 (1-2), 229 (409), 246, 2016

33. FARHAT N., ELKHOUNI A., ZORRIG W., SMAOUI A., ABDELLY C., RABHI M. Effects of magnesium deficiency on photosynthesis and carbohydrate partitioning. Acta Physiologiae Plantarum, 38 (6) 145, 2016.

34. REHMAN H. UR, ALHARBY H.F., ALZAHRANI Y., RADY M.M. Magnesium and organic biostimulant integrative application induces physiological and biochemical changes in sunflower plants and its harvested progeny on sandy soil. Plant Physiology and Biochemistry, 97 (126) 105. 2018.

35. GILROY S., BIAŁASEK M., SUZUKI N., GÓRECKA M., DEVIREDDY A.R., KARPIŃSKI S., MITTLER R. ROS, calcium, and electric signals: key mediators of rapid systemic signaling in plants. Plant Physiology. 1606 (171), 1615, 2016.

36. AHMAD P., SARWAT M., BHAT N.A., WANI M.R., KAZI A.G., TRAN L.S.P. Alleviation of cadmium toxicity in Brassica juncea L. (Czern. \& Coss.) by calcium application involves various physiological and biochemical strategies. PloS one. 10 (1), 0114571, 2015.

37. FARZADFAR S., ZARINKAMAR F., MODARRESSANAVY S., HOJATI M. Exogenously applied calcium alleviates cadmium toxicity in Matricaria chamomilla $L$. plants. Environ Sci Pollut Res. 1413 (3) 1422, 2013. 
38. TALUKDAR D. Exogenous calcium alleviates the impact of cadmium-induced oxidative stress in Lens culinaris Medic. seedlings through modulation of antioxidant enzyme activities. J Crop Sci Biotechnol. 325 (15), 334, 2012.

39. MEENA V.S., MAURYA B.R., VERMA J.P., MEENA R.S. (eds) Potassium solubilizing microorganisms for sustainable agriculture. Springer, India. 1, 2016.

40. WANG M., ZHENG Q., SHEN Q., GUO S. The critical role of potassium in plant stress response. Int J Mol Sci. 7370 (14) 90, 2013.

41. SIDDIQUI M.H., AL-WHAIBI M.H., SAKRAN A.M., BASALAH M.O., ALI H.M. Effect of Calcium and Potassium on Antioxidant System of Vicia faba L. Under Cadmium Stress. International Journal of Molecular Sciences, 6604 (13), 6619, 2012.

42. LAMBERS H., MARTINOIA E., RENTON M. Plant adaptations to severely phosphorus-impoverished soils. Current Opinion in Plant Biology, 23 (25), 31, 2015.

43. BLOOMFIELD K.J., DOMINGUES T.F., SAIZ G., BIRD M.I., CRAYN D.M., FORD A., METCALFE D., FARQUHAR G.D., LLOYD J. Contrasting photosynthetic characteristics of forest vs. savanna species (far North Queensland, Australia). Biogeosciences, 7331 (11), 7347, 2014.

44. AHMAD M., USMAN A.R.A., AL-FARAJ A.S., AHMAD M., SALLAM A., AL-WABEL M.I. Phosphorus-loaded biochar changes soil heavy metals availability and uptake potential of maize (Zea mays L.) plants. Chemosphere, 327 (194), 339, 2018.

45. CLARKSON T.W., NORDBERG G.F., SAGER P.R. Reproductive and developmental toxicity of metals. Scandinavian journal of work, environment and health, 145, 1985.
46. SOFO A., MOREIRA I., GATTULLO C.E., MARTINS L.L., MOURATO M. Antioxidant responses of edible and model plant species subjected to subtoxic zinc concentrations. Journal of Trace Elements in Medicine and Biology, 261 (49), 268, 2018.

47. SRIVASTAVA S., SRIVASTAVA A.K., SABLOK G., DESHPANDE T.U., SUPRASANNA P. Transcriptomics profiling of Indian mustard (Brassica juncea) under arsenate stress identifies key candidate genes and regulatory pathways. Frontiers in plant science. 6, 646, 2015.

48. TAUQEER H.M., ALI S., RIZWAN M., ALI Q., SAEED R., IFTIKHAR U., AHMAD R., FARID M., ABBASI G.H. Phytoremediation of heavy metals by Alternanthera bettzickiana: Growth and physiological response. Ecotoxicol. Environ. Saf. 138 (126), 146, 2016.

49. AFSHAN S., ALI S., BHARWANA S.A., RIZWAN M., FARID M., ABBAS M., IBRAHIM F., MEHMOOD M.A., ABBASI G.H. Citric acid enhances the phytoextraction of chromium, plant growth and photosynthesis by alleviating the oxidative damages in Brassica napus L. Environ. Sci. Pollut. Res. 11679 (22), 11689, 2015.

50. HABIBA U., ALI S., FARID M., SHAKOOR M.B., RIZWAN M., IBRAHIM M., ABBASI G.H., HAYAT T., ALI B. EDTA enhanced plant growth, antioxidant defence system and phytoextraction of copper by Brassica napus L. Environ. Sci. Pollut. Res. 1534 (22),1544, 2015.

51. RUI H., CHEN C., ZHANG X., SHEN Z., ZHANG F. Cd-induced oxidative stress and lignification in the roots of two Vicia sativa $\mathrm{L}$. varieties with different Cd tolerances. Journal of Hazardous Materials, 304 (301), 313, 2016. 
